\title{
Applying Benford's Law to Examine the Quality of Reported Income Numbers of Unlisted Firms
}

\author{
Sudershan Kuntluru ${ }^{1}$, Rachappa Shette ${ }^{1} \&$ Achalapathi K. V. ${ }^{2}$ \\ ${ }^{1}$ Indian Institute of Management Kozhikode, Kerala, India \\ ${ }^{2}$ Department of Commerce, Osmania University, Hyderabad, Telangana, India \\ Correspondence: Rachapa Shette, Indian Institute of Management Kozhikode, IIMK Campus (P.O.), \\ Kunnamangalam, Kozhikode, India. E-mail: rachappa.s@iimk.ac.in
}

Received: September 18, 2015

Accepted: October 8, 2015

Online Published: November 25, 2015

doi:10.5539/ijef.v7n12p211

URL: http://dx.doi.org/10.5539/ijef.v7n12p211

\begin{abstract}
The present study makes an attempt to examine the quality of reported income numbers of unlisted firms in India. The Benford's Law is applied to examine the digital occurrence of reported income numbers of unlisted firms. The analysis is based on 43,996 reported annual income numbers of 22,147 sample firms during the financial years from 2000-01 to 2011-12. Further, the results are analyzed under four different scenarios viz., ownership, size, age and nature of industry. The empirical results show that the observed proportionate occurrence of zero is significantly less than the expected proportionate occurrence. These results are contrary to the findings of the related studies of listed companies. The results indicate lower quality of reported income numbers of unlisted firms. Based on the scenario analysis, the empirical results indicate that the proportionate occurrence of second single digits of state-owned unlisted firms confirm the Benford's Law. The present study contributes to the literature by examining the quality of reported income numbers of unlisted firms using the Benford's Law.
\end{abstract}

Keywords: Benford's law, income numbers, India, quality of earnings, state-owned, unlisted firms

\section{Introduction}

The existing literature on quality of earnings is predominantly confined to listed companies (Moses, 1987; Carslaw, 1988; Jones 1991; Burgstahler \& Dichev, 1997; Penman \& Zhang, 2002; Roychowdhury, 2006). A few studies examine the quality of earnings of unlisted companies based on accruals and real measures which indicate mixed results (Beatty et al., 2002; Ball \& Shivakumar, 2005; Burgstahler et al., 2006; Chi et al., 2013; Hope et al., 2013). However, no study till date has focused on examining the quality of earnings of unlisted companies particularly based on Benford's Law. This law is widely used to examine the quality of reported income of listed firms and the listed firms' practice of rounding-up of reported earnings to achieve earnings thresholds is noticed. (Carslaw, 1988; Thomas, 1989; Shette \& Kuntluru, 2014). Such earnings thresholds are based on traditional $\$ 1.99$ pricing model. According to this model, $\$ 2.00$ is perceived by investors as substantially higher than $\$ 1.99$ income although the difference between the two numbers is a mere one cent. In India, for the year 2012-13, the total revenue and the total bank borrowings of unlisted firms accounted for 36.25 and 14.26 percent of Gross Domestic Product respectively. The sales revenue of sample unlisted firms accounted for one-third of the total sales revenue of all the listed firms. Kentor and Pike (1987a) report that valuation of unlisted firms is a highly complex process requiring information about several variables, many of which do not lead to an objective assessment of the firm valuation.

In this paper, we make an attempt to examine the quality of reported income numbers of unlisted firms in India. We propose that the results of unlisted firms would be different from listed companies for two reasons. One, listed companies raise funds from equity markets which are influenced by opportunistic earnings management (Teoh et al., 1998). Two, the listed firms are mostly manager-controlled firms and performance-based incentives of managers are dependent on reported earnings. In such cases, the managers would attempt to round up the earnings (Carslaw, 1988). Whereas, unlisted firms neither raise funds from equity markets nor they are manager-controlled firms. Thus, unlisted firms differ from listed companies in terms of capital market regulations, management control, accounting and reporting requirements and investors' expectations.

The present study is based on the annual earnings reported by 22,147 unlisted firms during the financial years 
from 2000-01 to 2011-12. Further, the results are analysed based on the four different scenarios like ownership, size, age and nature of industry. We apply Benford's Law to examine the digital occurrence of reported income numbers of unlisted firms. The analysis is based on observed deviation percent of left-most-side first single digit, second single digit and first two digits of reported income numbers of unlisted firms. It is found that there is a significant deviation of first and second single digits from left most side of reported income numbers of unlisted firms. The observed percent deviation of zero as second single digit in reported income of unlisted firms is contrary to the findings of studies on listed companies.

The findings of this study show the lower quality of reported income numbers of unlisted firms. It could be due to limited regulatory environment, less external demand for financial reporting quality and private communication of earnings to external stakeholders. The present study contributes to the body of knowledge by analysing the quality of reported income numbers of unlisted firms which play major role in the corporate world. The results are particularly useful to bankers, credit analysts, investment bankers, acquiring firms of unlisted firms and regulators.

The remainder of the paper is divided into five sections. Section 2 presents review of literature and development of hypothesis. Section 3 describes the sample and the data source. Section 4 discusses research methodology. Section 5 presents results and analysis. Lastly, section 6 concludes.

\section{Review of Literature and Hypothesis Development}

Quality of reported earnings is one of the widely researched topics in the accounting domain. However, most of the existing literature focuses on listed companies. Various measures like discretionary accruals, real measures, earnings thresholds, income smoothing, earnings conservatism and digital analysis are widely used for examining the quality of the earnings (Moses, 1987; Carslaw, 1988; Jones 1991; Burgstahler \& Dichev, 1997; Penman \& Zhang, 2002; Roychowdhury, 2006). Conversely, very few studies focus on examining the earnings quality of unlisted companies based on accrual and real measures. These studies find that the earnings quality of unlisted companies is better than that of listed companies (Beatty et al., 2002; Givoly et al., 2010; Chi et al., 2013). Whereas, some of the studies find that the earnings quality of unlisted companies is low due to the lack of capital market pressures and institutional factors. It is also observed that demand factor and opportunistic factor are the explanations for low earnings quality (Penno et al., 1986; Ball \& Shivakumar, 2005; Burgstahler et al., 2006; Hope et al., 2013). The listed companies report higher quality of earnings when there is demand for high quality of earnings from external stakeholders and report lower quality of earnings when they are opportunistic. Similarly, unlisted firms report high quality of earnings, when they are least opportunistic and report low quality of earnings when there is no demand for higher quality of earnings.

Kentor and Pike (1987b) find that historical and potential earnings constitute the most important variables in business valuations of unlisted companies. They play a vital role in mergers and acquisitions where three out of four acquired firms are unlisted firms. The shareholders of listed acquiring firms give higher value for an acquisition of unlisted firms as compared to the listed firms. At the time of the announcement of acquisition, shareholders of acquiring firms make positive abnormal stock returns when target firm is unlisted firm and make negative abnormal stock returns when target firm is listed firm (Rani et al., 2013; Feito-Reuiz et al., 2014). The abnormal returns due to the acquisition of unlisted firms are not sustainable in the long term due to limited accounting disclosures practices of unlisted firms (Ekkayokkaya et al., 2009).

Digital analysis using Benford's Law is one of the widely used methods to evaluate the quality of reported and estimated earnings of listed companies. Carslaw (1988) is the first to examine the digits of reported income and document rounding up behaviour in reported income numbers of listed companies in New Zealand. Later on, Thomas (1989) confirms the existence of rounding up behaviour of listed companies in United States of America (USA). Subsequently, other studies like Shette and Kuntluru (2014) in India, Skousen et al. (2004) in Japan, Niskanen aand Kelhoharju (2000) in Finland, Kinnunen and Koskela (2003) across eighteen different countries, Caneghem (2002) and Caneghem (2004) in United Kingdom find rounding up behavior in the reported income of listed companies. However, no study till date has focused on examining the quality of reported incomes of unlisted companies based on Benford's Law. Thus, the present study makes an attempt to examine the quality of reported income numbers of a large sample of Indian unlisted firms using Benford's Law. Therefore, the following two null hypotheses are proposed for empirical examination of 'zero' and 'nine' as second single digits from left-most-side of the reported incomes.

H1: The proportionate observed occurrence of zero as second single digit of reported income of unlisted firms does not deviate from the proportionate expected occurrence.

H2: The proportionate observed occurrence of nine as second single digit of reported income of unlisted firms 
does not deviate from the proportionate expected occurrence.

\section{Sample and Data Collection}

The present study is based on annual reported income numbers of 22,147 sample unlisted firms over a period of 12 years that is from 2000-01 to 2011-12. The data is collected from Prowess database of Centre for Monitoring Indian Economy (CMIE). The Prowess database maintains the data of only those unlisted firm-years to which Generally Agreed Accounting Principles (GAAP) are applicable. Such firm-years account for 103,975 income numbers out of which, we consider only 43,996 income numbers having minimum of two digits as positive income numbers. Thus, the analysis is based on 43,996 positive income numbers of 22,147 sample firms. The descriptive statistics and the year-wise classification of the sample income numbers are presented in Tables 1 and 2 respectively.

Table 1. Descriptive statistics of sample unlisted firms (INR in lakhs)

\begin{tabular}{lr}
\hline & Positive PATs \\
\hline Mean & 1,829 \\
Median & 129 \\
Standard Deviation & 13,825 \\
Minimum & 10 \\
Maximum & $10,18,329$ \\
No. of Observations (n) & 43,996 \\
\hline
\end{tabular}

Table 2. Year-wise number of observations

\begin{tabular}{cc}
\hline Year & Number of Positive PATs \\
\hline $2000-01$ & 2,020 \\
$2001-02$ & 2,196 \\
$2002-03$ & 2,999 \\
$2003-04$ & 3,724 \\
$2004-05$ & 4,314 \\
$2005-06$ & 4,843 \\
$2006-07$ & 5,007 \\
$2007-08$ & 5,223 \\
$2008-09$ & 4,782 \\
$2009-10$ & 4,899 \\
$2010-11$ & 2,528 \\
$2011-12$ & 1,461 \\
Total & 43,996 \\
\hline
\end{tabular}

\section{Research Methodology}

Based on the Benford's Law (Benford, 1938), the deviation percent of left-most-side first single digit, second single digit and first two digits of reported income are considered for analyzing the quality of reported incomes. The observed deviation percent is the difference between observed proportionate occurrence and expected proportionate occurrence of digits. The expected proportionate occurrence of each digit is derived through Benford's Law with the help of the following three formulas.

The left-most-side first single digit can be any number ranging from 1 to 9 . The probability (P) of " $a$ " as the first digit is:

$$
\mathrm{P}(\mathrm{a})=\log _{10}(a+1)-\log _{10}(a)
$$

The left-most-side second single digit can be any number ranging from zero to nine. The probability of " $b$ " as the second single digit is:

$$
\mathrm{P}(\mathrm{b})=\sum_{a=1}^{9}\left(\log _{10}\left(a+\frac{b+1}{10}\right)-\log _{10}\left(a+\frac{b}{10}\right)\right)
$$

Similarly, the left-most-side first two digits can be any number ranging from 10 to 99 . The probability of "a" as 
the first digit and "b" as the second digit is

$$
\mathrm{P}(\mathrm{ab})=\log _{10}\left(a+\frac{b+1}{10}\right)-\log _{10}\left(a+\frac{b}{10}\right)
$$

The above methodology is widely applied by various researchers while evaluating the quality of earnings of listed companies (Carslaw, 1988; Thomas, 1989; Das \& Zhang, 2003; Dechow \& You, 2012). In addition to this, Benford's Law is also applied to evaluate the quality of reported numbers of off-balance sheet items (Ozer \& Babacan, 2013), financial statements of 50 states in United States (Johnson \& Waggenmann, 2013); international macroeconomic statistics (Nye \& Moul, 2007) and analysts' forecasted numbers (Dechow \& You, 2012). The Z-statistic is used to test the hypothesis as to whether the observed proportionate occurrence is significantly deviating from expected the proportionate occurrence at one and five percent levels of significance. The equation of Z-statistic is:

$$
\text { Z-statistic }=\frac{p-p_{0}}{\sqrt{\frac{p_{0}\left(1-p_{0}\right)}{n}}}
$$

Where, $p$ =actual frequency; $p_{0}=$ expected frequency; and $\mathrm{n}=$ number of observations.

Further, the second single digit of reported income of unlisted firms is examined under four different scenarios viz., ownership, size, age and nature of industry.

\section{Results and Analysis}

Table 3 presents the results of left-most-side first single digit, second single digit and first two digits of reported income numbers. The empirical results show positive observed deviation percent in case of 1 and 2 and negative observed deviation percent in case of 3, 4, 5, 6, 7, 8, and 9 as first single digits. This implies that the observed proportionate occurrence of 1 and 2 is significantly higher and is lower in case of all other digits. Therefore, the observed occurrence of first single digits deviates from the Benford's Law.

The empirical results show significant negative observed deviation percent in case of zero and significant positive observed deviation percent in case of 1, 2, 3, 4 and 5 as second single digits. The observed deviation percent of zero is negative 3.79 percent which is the highest compared to those of other second single digits. Contrary to this, the observed deviation percent in case of reported income of listed firms in India is positive 0.78 percent (Shette \& Kuntluru, 2014) and in USA, it is positive 1.09 percent (Thomas, 1989). As observed, the negative observed deviation of zero has been distributed among all the first two digits having zero as second single digit. The results are statistically significant. These results are contrary to the findings of the related studies of listed companies. Hence, we reject hypothesis H1. Whereas, the observed proportionate occurrence of nine confirms the expected proportionate occurrence. Hence, we fail to reject the hypothesis $\mathrm{H} 2$.

Thus, in case of reported incomes of unlisted firms, the observed proportionate occurrence of zero as left-most-side second single digit does not confirm the expected proportionate occurrence. The results of unlisted firms are opposite to the findings of the listed companies. The results imply that the unlisted firms are involved in reporting lower income numbers. The possible reasons for deflated earnings could be to prevent the entry of new firms, lack of earnings thresholds and lack of pressure from capital market.

Table 3. Deviation from expected proportion ${ }^{1}$ (percent of sample) of first and second digits of annual reported

\begin{tabular}{|c|c|c|c|c|c|c|c|c|c|c|c|}
\hline \multirow[b]{2}{*}{ First Digit } & \multicolumn{11}{|c|}{ Second Digit } \\
\hline & 0 & 1 & 2 & 3 & 4 & 5 & 6 & 7 & 8 & 9 & Total \\
\hline \multirow[t]{3}{*}{1} & $-0.54^{*}$ & $0.95^{*}$ & $0.76^{*}$ & $0.56^{*}$ & $0.57 *$ & $0.47 *$ & $0.31 *$ & $0.35^{*}$ & $0.26^{*}$ & $0.40^{*}$ & $4.10^{*}$ \\
\hline & 4.14 & 3.78 & 3.48 & 3.22 & 3.00 & 2.80 & 2.63 & 2.48 & 2.35 & 2.23 & 30.10 \\
\hline & 5.65 & 10.44 & 8.66 & 6.62 & 7.07 & 5.92 & 4.10 & 4.78 & 3.65 & 5.72 & 18.74 \\
\hline \multirow[t]{3}{*}{2} & $-0.53^{*}$ & $0.33^{*}$ & 0.12 & $0.16^{*}$ & $0.20^{*}$ & 0.11 & $0.23^{*}$ & $0.12 *$ & $0.19 *$ & $0.13^{*}$ & $1.05^{*}$ \\
\hline & 2.12 & 2.02 & 1.93 & 1.85 & 1.77 & 1.70 & 1.64 & 1.58 & 1.52 & 1.47 & 17.61 \\
\hline & 7.75 & 4.99 & 1.79 & 2.47 & 3.14 & 1.75 & 3.86 & 2.03 & 3.17 & 2.19 & 5.78 \\
\hline \multirow[t]{3}{*}{3} & $-0.52^{*}$ & $0.12 *$ & $0.13^{*}$ & -0.01 & 0.05 & 0.07 & -0.07 & -0.02 & -0.01 & -0.01 & -0.28 \\
\hline & 1.42 & 1.38 & 1.34 & 1.30 & 1.26 & 1.22 & 1.19 & 1.16 & 1.13 & 1.10 & 12.49 \\
\hline & 9.28 & 2.22 & 2.33 & 0.14 & 0.99 & 1.25 & 1.43 & 0.47 & 0.19 & 0.26 & 1.80 \\
\hline
\end{tabular}
income numbers of unlisted firms $(n=43,996)$ 


\begin{tabular}{|c|c|c|c|c|c|c|c|c|c|c|c|}
\hline \multirow[t]{3}{*}{4} & $-0.44^{*}$ & -0.05 & 0.01 & 0.00 & $0.11^{*}$ & 0.00 & 0.03 & -0.04 & -0.07 & -0.06 & $-0.51^{*}$ \\
\hline & 1.07 & 1.05 & 1.02 & 1.00 & 0.98 & 0.95 & 0.93 & 0.91 & 0.90 & 0.88 & 9.69 \\
\hline & 8.88 & 1.00 & 0.30 & 0.01 & 2.26 & 0.05 & 0.60 & 0.92 & 1.62 & 1.38 & 3.62 \\
\hline \multirow[t]{3}{*}{5} & -0.38 & 0.02 & -0.04 & 0.03 & -0.09 & -0.03 & -0.03 & 0.00 & -0.02 & -0.11 & -0.65 \\
\hline & 0.86 & 0.84 & 0.83 & 0.81 & 0.80 & 0.78 & 0.77 & 0.76 & 0.74 & 0.73 & 7.92 \\
\hline & 8.75 & 0.52 & 0.89 & 0.68 & 2.18 & 0.72 & 0.67 & 0.02 & 0.48 & 2.75 & 5.08 \\
\hline \multirow[t]{3}{*}{6} & $-0.40^{*}$ & -0.04 & -0.04 & -0.01 & -0.04 & -0.03 & -0.06 & -0.03 & $-0.09 *$ & -0.05 & $-0.80 *$ \\
\hline & 0.72 & 0.71 & 0.69 & 0.68 & 0.67 & 0.66 & 0.65 & 0.64 & 0.63 & 0.62 & 6.69 \\
\hline & 10.04 & 1.01 & 0.90 & 0.28 & 1.12 & 0.81 & 1.56 & 0.78 & 2.28 & 1.45 & 6.68 \\
\hline \multirow[t]{3}{*}{7} & $-0.38^{*}$ & -0.02 & $-0.11^{*}$ & $-0.09 *$ & $-0.10 *$ & -0.02 & -0.04 & $-0.11^{*}$ & -0.04 & $-0.09 *$ & $-0.99 *$ \\
\hline & 0.62 & 0.61 & 0.60 & 0.59 & 0.58 & 0.58 & 0.57 & 0.56 & 0.55 & 0.55 & 5.80 \\
\hline & 10.06 & 0.57 & 3.12 & 2.49 & 2.85 & 0.45 & 1.00 & 2.97 & 1.25 & 2.48 & 8.92 \\
\hline \multirow[t]{3}{*}{8} & $-0.32^{*}$ & -0.04 & -0.07 & -0.05 & -0.05 & -0.04 & $-0.10 *$ & $-0.11^{*}$ & $-0.11 *$ & $-0.09 *$ & $-0.99 *$ \\
\hline & 0.54 & 0.53 & 0.53 & 0.52 & 0.51 & 0.51 & 0.50 & 0.50 & 0.49 & 0.49 & 5.12 \\
\hline & 9.27 & 1.21 & 1.95 & 1.38 & 1.41 & 1.17 & 3.10 & 3.15 & 3.40 & 2.85 & 9.38 \\
\hline \multirow[t]{3}{*}{9} & $-0.27^{*}$ & $-0.07 *$ & -0.03 & -0.06 & $-0.09 *$ & -0.05 & -0.05 & $-0.07 *$ & $-0.13 *$ & $-0.11 *$ & $-0.92 *$ \\
\hline & 0.48 & 0.47 & 0.47 & 0.46 & 0.46 & 0.45 & 0.45 & 0.45 & 0.44 & 0.44 & 4.58 \\
\hline & 8.15 & 2.07 & 0.95 & 1.85 & 2.69 & 1.64 & 1.50 & 2.15 & 4.03 & 3.62 & 9.27 \\
\hline \multirow[t]{3}{*}{ Total } & $-3.79^{*}$ & $1.21 *$ & $0.79 *$ & $0.53 *$ & $0.56^{*}$ & $0.47^{*}$ & 0.23 & 0.10 & -0.02 & -0.01 & \\
\hline & 11.97 & 11.39 & 10.82 & 10.43 & 10.03 & 9.67 & 9.34 & 9.04 & 8.76 & 8.50 & 100 \\
\hline & 24.46 & 7.99 & 5.32 & 3.62 & 3.88 & 3.35 & 1.62 & 0.73 & 0.18 & 0.06 & \\
\hline
\end{tabular}

Note. ${ }^{1}$ The first line in each cell is observed deviation percent (difference between observed proportion and expected proportion) and other two numbers in each cell report the expected proportions, and a Z-statistics (in italics). * represents deviations significantly different from zero at the five percent level of significance

\subsection{Scenario Analysis}

The empirical results of positive reported income of all the four scenarios are presented in Table 4. First, the sample firms are classified into four categories based on ownership by the state, Indian private groups, Indian individuals, foreign individuals and groups. The existing literature finds higher quality of earnings of state-owned listed companies as compared to privately owned firms in China (Ding et al., 2007; and Wang \& Yung, 2011). Therefore, we propose that the observed proportionate occurrence of second single digits of state-owned firms do not deviate from the expected proportionate occurrence.

Table 4. Deviation from expected proportion ${ }^{1}$ (percent of sample) of second single digits of reported income numbers of unlisted firms

\begin{tabular}{|c|c|c|c|c|c|c|c|c|c|c|}
\hline Second Digit & $\mathbf{0}$ & 1 & 2 & 3 & 4 & 5 & 6 & 7 & 8 & 9 \\
\hline Expected Proportion & 11.97 & 11.39 & 10.82 & 10.43 & 10.03 & 9.67 & 9.34 & 9.04 & 8.76 & 8.50 \\
\hline \multicolumn{11}{|l|}{ Panel A: Ownership } \\
\hline \multirow[t]{2}{*}{ State-owned $(n=3,199)$} & 0.10 & 1.05 & 0.46 & 0.48 & -0.18 & -0.23 & $-1.55^{*}$ & 0.19 & 0.56 & -0.81 \\
\hline & 0.17 & 1.87 & 0.84 & 0.88 & 0.35 & 0.44 & 3.02 & 0.37 & 1.12 & 1.64 \\
\hline \multirow[t]{2}{*}{ Indian Private Group $\quad(n=11,815)$} & $-2.84^{*}$ & $1.15^{*}$ & 0.45 & $0.79 *$ & 0.40 & 0.01 & 0.30 & -0.02 & -0.13 & -0.06 \\
\hline & 9.50 & 3.95 & 1.58 & 2.81 & 1.43 & 0.05 & 1.13 & 0.08 & 0.51 & 0.24 \\
\hline \multirow[t]{2}{*}{ Indian Individual $(\mathrm{n}=25,800)$} & $-4.96^{*}$ & $1.41 *$ & $1.03 *$ & $0.45^{*}$ & $0.65^{*}$ & $0.82 *$ & $0.40^{*}$ & 0.14 & -0.04 & 0.17 \\
\hline & 24.53 & 7.11 & 5.33 & 2.35 & 3.46 & 4.44 & 2.23 & 0.80 & 0.25 & 0.96 \\
\hline \multirow[t]{2}{*}{ Foreign Individuals \& Groups $\quad(n=3,182)$} & $-1.72 *$ & -0.01 & 0.40 & 0.25 & $1.16^{*}$ & 0.07 & 0.28 & 0.11 & -0.05 & -0.42 \\
\hline & 2.99 & 0.02 & 0.72 & 0.47 & 2.17 & 0.14 & 0.54 & 0.22 & 0.10 & 0.86 \\
\hline \multicolumn{11}{|l|}{ Panel B: Size (Rs in millions) } \\
\hline \multirow[t]{2}{*}{ Between Rs 1 to Rs $5 \quad(n=13,450)$} & $-10.58 *$ & $2.14 *$ & $1.51^{*}$ & $1.02 *$ & $1.63^{*}$ & $0.88 *$ & $1.01 *$ & $0.66^{*}$ & $0.92 *$ & $0.87 *$ \\
\hline & 37.79 & 7.79 & 5.62 & 3.89 & 6.31 & 3.46 & 4.01 & 2.67 & 3.79 & 3.61 \\
\hline \multirow[t]{2}{*}{ Between Rs 5 to Rs $10(n=6,197)$} & $-11.45^{*}$ & 0.75 & 0.18 & $1.41 *$ & $0.83 *$ & $1.85^{*}$ & $1.65^{*}$ & $1.70 *$ & $1.46^{*}$ & $1.68 *$ \\
\hline & 27.77 & 1.85 & 0.46 & 3.63 & 2.17 & 4.94 & 4.47 & 4.66 & 4.06 & 4.75 \\
\hline \multirow[t]{2}{*}{ Between Rs 10 to Rs $50(n=12,670)$} & $1.87 *$ & $1.01 *$ & $0.76^{*}$ & -0.27 & 0.28 & -0.20 & $-0.78 *$ & $-0.80^{*}$ & $-1.09 *$ & $-0.73^{*}$ \\
\hline & 6.48 & 3.58 & 2.74 & 0.98 & 1.07 & 0.75 & 3.02 & 3.15 & 4.32 & 2.93 \\
\hline \multirow[t]{2}{*}{ Above Rs $50(n=11,674)$} & $1.93^{*}$ & $0.61 *$ & 0.32 & 0.35 & -0.53 & -0.01 & -0.33 & -0.41 & $-0.75^{*}$ & $-1.13^{*}$ \\
\hline & 6.44 & 2.08 & 1.12 & 1.24 & 1.91 & 0.02 & 1.24 & 1.54 & 2.86 & 4.39 \\
\hline
\end{tabular}




\begin{tabular}{lccccccccccc}
\hline Panel C: Age & & & & & & & & & \\
Younger firms (n=19,469) & $-3.57^{*}$ & $1.47^{*}$ & $0.82^{*}$ & 0.11 & 0.34 & $0.74^{*}$ & 0.18 & 0.04 & -0.11 & 0.03 \\
& 15.35 & 6.47 & 3.69 & 0.51 & 1.58 & 3.49 & 0.87 & 0.20 & 0.53 & 0.16 \\
Older firms (n=24,137) & $-4.02^{*}$ & $0.98^{*}$ & $0.79^{*}$ & $0.91^{*}$ & $0.76^{*}$ & 0.27 & 0.28 & 0.13 & 0.00 & -0.04 \\
& 19.25 & 4.78 & 3.96 & 4.63 & 3.92 & 1.43 & 1.51 & 0.68 & 0.01 & 0.20 \\
Panel D: Industry & & & & & & & & & & \\
Manufacturing(n=17,426) & $-3.12^{*}$ & $0.78^{*}$ & $0.57^{*}$ & 0.33 & $0.75^{*}$ & 0.32 & 0.31 & 0.15 & -0.06 & 0.04 \\
& 12.71 & 3.25 & 2.42 & 1.41 & 3.28 & 1.44 & 1.40 & 0.68 & 0.29 & 0.21 \\
Service(n=18,452) & $-3.93^{*}$ & $1.66^{*}$ & $0.73^{*}$ & $0.58^{*}$ & 0.43 & $0.57^{*}$ & 0.10 & 0.12 & -0.18 & -0.02 \\
& 16.43 & 7.08 & 3.18 & 2.60 & 1.94 & 2.62 & 0.46 & 0.59 & 0.86 & 0.12 \\
Others(n=8,118) & $-4.88^{*}$ & $1.11^{*}$ & $1.40^{*}$ & $0.83^{*}$ & 0.44 & 0.57 & 0.33 & -0.05 & 0.41 & -0.09 \\
& 13.56 & 3.16 & 4.05 & 2.43 & 1.32 & 1.73 & 1.03 & 0.17 & 1.30 & 0.28 \\
\hline
\end{tabular}

Note. ${ }^{1}$ The first line in each cell is observed deviation percent (difference between observed proportion and expected proportion) and second line in each cell is a Z-statistics (in italics). * represents deviations significantly different from zero at the five percent level of significance.

As per Panel A of Table 4, the empirical results show that the observed proportionate occurrence of all second single digits of reported income numbers of state-owned firms do not deviate from the Benford's law. Whereas, the proportionate occurrence of reported income numbers of other ownership categories significantly deviate from the Benford's Law. The observed deviation percent is highest in case of firms owned by Indian individuals. Thus, the quality of reported income numbers of state-owned unlisted firms is high as compared to those of other ownership categories in India. These results are consistent with the existing literature. The possible reasons for such results of unlisted firms could be because of public accountability, transparency, entry restrictions and service motive.

Second, the size of the sample firms is measured in terms of reported income in Indian rupees (Rs) in millions. Based on the size, the sample firms are classified into four different groups viz., Rs. 1 million to 5 million, Rs. 5 million to 10 million, Rs. 10 million to 50 million and above Rs. 50 million. It is proposed that higher observed deviation exists when income size is small and vice versa. As per Panel B of Table 4, we observe existence of significant observed deviations in reported income across different sizes of income. As proposed, the empirical results show that the observed deviations are high when income numbers are less than Rs. 10 million.

Third, the sample firms are classified into younger firms and older firms based on the median age of 21 years. Based on existing literature of listed companies, it is proposed that the observed deviation percent in younger unlisted firms would be higher than that of the older unlisted firms (Jain \& Kini, 1994 and Teoh et. al, 1998). As per Panel C of Table 4, we find significant negative observed deviation of zero as second single digit of reported income of both the groups. The empirical results indicate that the proportionate occurrence of reported income numbers of both younger and older unlisted firms deviate from the Benford's Law. It is found that the observed deviation percent of older unlisted firms is higher than that of the younger unlisted firms. These findings are contrary to the findings of related studies in the existing literature based on listed companies.

Lastly, the reported income numbers are classified based on the nature of the industry. Accordingly, the sample firms are classified into three industry categories viz., manufacturing, service and other industries. It is proposed that the number of observed deviations of second single digits of service industry would be higher as compared to those of the manufacturing and other industries. As per Panel D of Table 4, it is found that negative observed deviation of zero as second single digit is the largest and statistically significant in case of reported income of all the industries. But the number and magnitude of observed deviation percent are higher in case of service industry.

\section{Conclusion}

The novelty of the present study is to examine the quality of reported income numbers of unlisted firms by applying Benford's Law. The existing literature is confined to listed companies only. We examine the digital occurrence of first single digit, second single digit and first two digits from left-most-side of reported income numbers of unlisted firms. It is hypothesized that the observed proportionate occurrence of first and second single digits does not deviate from the expected proportionate occurrence. The empirical results show that the observed proportionate occurrence of zero is less than the expected proportionate occurrence. This implies lower quality of reported income numbers of unlisted firms and the practice of under-reporting the income. These results are contrary to the findings of the studies on listed companies. The possible reasons for such observations could be limited regulatory environment, low external demand for financial reporting quality, private 
communication of earnings to external stakeholders, limited disclosure practices, inaccessibility of financial statements, private funding and non-big four auditors. Based on the scenario analysis, the empirical results indicate that the proportionate occurrence of second single digits of state-owned unlisted firms confirm the Benford's Law. It implies that state-owned unlisted firms report higher quality of reported income numbers. The present study contributes to the literature by examining the quality of reported income numbers of unlisted firms using Benford's Law. The results are useful to regulators, acquiring firms in case of mergers and acquisitions, investors and management practitioners. Future research can examine the determinants of quality of reported income numbers of unlisted firms.

\section{References}

Ball, R., \& Shivakumar, L. (2005). Earnings quality in U.K. private firms: Comparative loss recognition $\begin{array}{llll}\text { timeliness. Journal of Accounting and Economics, } & \text { 39, }\end{array}$ http://dx.doi.org/10.1016/j.jacceco.2004.04.001

Beatty, A. L., Ke, B. \& Petroni, K. R. (2002). Earnings Management to Avoid Earnings Declines across Publicly and Privately Held Banks. The Accounting Review, 77(3), 547-570. http://dx.doi.org/10.2308/accr.2002.77.3.547

Benford, F. (1938). The law of anomalous matters. Proceedings of the American Philosophical Society, 78, 551-572.

Burgstahler, D. C., \& Dichev, I. (1997). Earnings management to avoid earnings decreases and losses. Journal of Accounting and Economics, 24, 99-126. http://dx.doi.org/10.1016/S0165-4101(97)00017-7

Burgstahler, D. C., Hail, L., \& Leuz, C. (2006). The Importance of Reporting Incentives: Earnings Management in European Private and Public Firms. The Accounting Review, 81(5), 983-1016. http://dx.doi.org/10.2308/accr.2006.81.5.983

Caneghem, T. V. (2002). Earnings Management Induced by Cognitive Reference Points. British Accounting Review, 34(2), 167-178. http://dx.doi.org/10.1006/bare.2002.0190

Caneghem, T. V. (2004). The Impact of Audit Quality on Earnings Rounding-Up Behaviour: Some UK Evidence. European Accounting Review, 13(4), 771-786. http://dx.doi.org/10.1080/0963818042000216866

Carslaw, A. P. N. C. (1988). Anomalies in Income Numbers: Evidence of Goal Oriented Behavior. The Accounting Review, 63(2), 321-327.

Chi, W., Dhaliwal, D., Li, O. Z., \& Lin, T. (2013). Voluntary Reporting Incentives and Reporting Quality: Evidence from a Reporting Regime Change for Private Firms in Taiwan. Contemporary Accounting Research, 30(4), 1462-1489. http://dx.doi.org/10.1111/1911-3846.12003

Das, S., \& Zhang, H. (2003). Rounding-up in reported EPS, behavioral thresholds, and earnings management. Journal of Accounting and Economics, 35, 31-50. http://dx.doi.org/10.1016/S0165-4101(02)00096-4

Dechow, P. M., \& You, H. (2012). Analysts' Motives for Rounding EPS Forecasts. The Accounting Review, 87(6), 1939-1966. http://dx.doi.org/10.2308/accr-50226

Ding, Y., Zhang, H., \& Zhang, J. (2007). Private vs State Ownership and Earnings Management: Evidence from Chinese listed companies. Corporate Governance: An International Review, 15(2), 223-238. http://dx.doi.org/10.1111/j.1467-8683.2007.00556.x

Ekkayokkaya, M., Holmes, P., \& Paudyal, K. (2009). Limited Information and the Sustainability of Unlisted-Target Acquirers' Returns. Journal of Business Finance and Accounting, 36(9), 1201-1227. http://dx.doi.org/10.1111/j.1468-5957.2009.02166.x

Feito-Reuiz, I., Fernandez, A, I., \& Menendez-Requejo, S. (2014). Determinants of the acquisition of listed versus unlisted firms in different legal and institutional environments. Applied Economics, 46(23), 2814-2832. http://dx.doi.org/10.1080/00036846.2014.914146

Givoly, D., Hayn, C. K., \& Katz, S. P. (2010). Does Public Ownership of Equity Improve Earnings Quality? The Accounting Review, 85(1), 195-225. http://dx.doi.org/10.2308/accr.2010.85.1.195

Hope, O. K., Thomas, W. B., \& Vyas, D. (2013). Financial Reporting Quality of U.S.Private and Public Firms. The Accounting Review, 88(5), 1715-1742. http://dx.doi.org/10.2308/accr-50494

Jain, B. A., \& Kini, O. (1994). The Post-Issue Operating Performance of IPO companies. Journal of Finance, 49(5), 1699-1726. http://dx.doi.org/10.1111/j.1540-6261.1994.tb04778.x 
Johnson, G. G., \& Waggenmann, J. (2013). Exploratory Research Applying Benford's Law to Selected Balances in the Financial Statements of State States. Academy of Accounting and Financial Studies Journal, 17(3), $31-44$.

Jones, J. (1991). Earnings management during import relief investigations. Journal of Accounting Research, 29, 193-228. http://dx.doi.org/10.2307/2491047

Kentor, J., \& Pike, R. (1987a). Valuing Unlisted Shares: A Dual Approach to the Major Information $\begin{array}{lllll}\text { Determinants. } \quad \text { Managerial and Decision } & \text { Economics, } & \text { 8, } 227 .\end{array}$ http://dx.doi.org/10.1002/mde.4090080308

Kentor, J., \& Pike, R. (1987b). The Determinants of the Value of Unlisted Shares: Opinions of the Professional Valuers in Canada. Accounting and Business Research, 17(66), 109-115. http://dx.doi.org/10.1080/00014788.1987.9729789

Kinnunen, J., \& Koskela, M. (2003). Who is Miss World in Cosmetic Earnings Management? A Cross-National Comparison of Small Upward Rounding of Net Income Numbers among Eighteen Countries. Journal of International Accounting Research, 2, 39-68. http://dx.doi.org/10.2308/jiar.2003.2.1.39

Moses, O. D. (1987). Income smoothing and incentives: Empirical tests using accounting changes. The AccountingReview, 62(2), 358-377.

Niskanen. J., \& Keloharju, M. (2000). Earnings cosmetics in a Tax Driven Accounting Environment: Evidence from Finnish Public Firms. European Accounting Review, 9(3), 443-452. http://dx.doi.org/10.1080/09638180020017159

Nye. J., \& Moul, C. (2007). The Political Economy of Numbers: On the Application of Benford's Law to International Macroeconomic Statistics. The B.E. Journal of Macroeconomics, 7(1), 1-12. http://dx.doi.org/10.2202/1935-1690.1449

Ozer, G., \& Babacan, B. (2013). Benford's Law and Digital Analysis: Application on Turkish Banking Sector. Business and Economics Research Journal, 4(1), 29-41.

Penman, S, H., \& Zhang, X, J. (2002). Accounting Conservatism, the Quality of Earnings, and Stock Returns. The Accounting Review, 77(2), 237-264. http://dx.doi.org/10.2308/accr.2002.77.2.237

Penno, M., \& Simon, D. T. (1986). Accounting Choice: Public versus Private Firms. Journal of Business Finance and Accounting, 13(4), 561-569. http://dx.doi.org/10.1111/j.1468-5957.1986.tb00518.x

Rani, N., Yadav, S. S., \& Jain, P. K. (2012). The Impact of Domestic Mergers and Acquisitions on Acquirer Shareholders' Wealth in India. Global Journal of Flexible Systems Management, 13(4), 179-193. http://dx.doi.org/10.1007/s40171-013-0022-0

Roychowdhury, S. (2006). Earnings management through real activities manipulation. Journal of Accounting and Economics, 42, 335-370. http://dx.doi.org/10.1016/j.jacceco.2006.01.002

Shette, R., \& Kuntluru, S. (2014). Rounding up in Reported Income Numbers: Evidence from Indian Companies. Review of Accounting and Finance, 13(2), 156-170. http://dx.doi.org/10.1108/RAF-04-2013-0042

Skousen, J. C., Guan, L., \& Wetzel, T. S. (2004). Anomalies and Unusual Patterns in Reported Earnings: Japanese Managers Round Earnings. Journal of International Financial Management, 15(3), 212-234. http://dx.doi.org/10.1111/j.1467-646X.2004.00108.x

Teoh, S. H., Welch, I., \& Wong, T. J. (1998). Earnings Management and the Long-Run Market Performance of Initial Public of offerings. The Journal of Finance 53(6), 1935-1974. http://dx.doi.org/10.1111/0022-1082.00079

Thomas, J. K. (1989). Unusual Patterns in Reported Earnings. The Accounting Review, LXIV(4), 773-787.

Wang, L., \& Yung, K. (2011). Do State Enterprises Manage Earnings More than Privately Owned Firms? The Case of China. Journal of Business Finance and Accounting, 38(7\&8), 794-812. http://dx.doi.org/10.1111/j.1468-5957.2011.02254.x

\section{Copyrights}

Copyright for this article is retained by the author(s), with first publication rights granted to the journal.

This is an open-access article distributed under the terms and conditions of the Creative Commons Attribution license (http://creativecommons.org/licenses/by/3.0/). 